\title{
Mitigation of Fluoride Toxicity by the Use of Thymoquinone in Adult Male Albino Rat
}

\author{
Rasha E. Abou Anza and Hoda Mohamed Salah Eldin1
}

${ }^{1}$ Forensic Medicine and Clinical Toxicology Department, Faculty of Medicine, Ain Shams University, Cairo, Egypt.

\begin{abstract}
Background: Fluoride is widely distributed in nature in many forms and its compounds are being used extensively. Increased oxidative stress is proposed to mediate the toxic effects of fluoride on soft tissues. Thymoquinone (TQ), the major bioactive ingredient isolated from Nigella sativa seed, has been studied for its anti-oxidant properties. Accordingly, this work was conducted to investigate the possible protective effects of TQ against sodium fluoride $(\mathrm{NaF})$-induced hematological and biochemical toxicity in male albino rats

Method: Seventy animals were divided into 7 equal groups. Group I served as negative control group. Group II or positive control group received distilled water orally. Group III received TQ orally at a dose of $10 \mathrm{mg} / \mathrm{kg}$ for 5 weeks. Group IV and group $\mathrm{V}$ were intoxicated with $\mathrm{NaF}$ orally in two different doses: $10 \mathrm{mg} / \mathrm{kg}$ and $20 \mathrm{mg} / \mathrm{kg}$ respectively for 4 weeks. Group VI was given $10 \mathrm{mg} / \mathrm{kg}$ TQ one week prior administration of both TQ and $\mathrm{Na} \mathrm{F}$ at a dose of $10 \mathrm{mg} / \mathrm{kg}$ for 4 weeks. Similarly group VII received $10 \mathrm{mg} / \mathrm{kg}$ TQ for one week then concomitantly with $\mathrm{Na} \mathrm{F}$ at a dose of $20 \mathrm{mg} / \mathrm{kg}$ for 4 weeks. At the end of the experiment, the animals were sacrificed and blood samples were obtained for assessment of hemoglobin ( $\mathrm{Hb}$ ) concentration, red cell count (RBC), total leucocytic count (TLC), platelet count, serum cholesterol, triglycerides (TG) and blood glucose level in addition to liver enzymes, total bilirubin level and total serum proteins. Oxidative indices including antioxidant enzyme superoxide dismutase (SOD), total antioxidant capacity (TAC), thiobarbituric acid reactive substances (TBARS) and advanced oxidation protein product (AOPP) were also assessed.

Results: NaF intoxicated groups showed significant alterations of hematological and biochemical indices with significantly depleted SOD, decreased TAC and concomitant increase in TBARS and AOPP. Pretreatment by TQ mitigated both hematological and biochemical changes induced by $\mathrm{NaF}$ probably due to its strong antioxidant activity.

Conclusions: The results obtained indicate the role of oxidative stress in NaF toxicity and suggest a possible protective effect of TQ against the toxicity of fluoride compounds.
\end{abstract}

Keywords Na fluoride, Thymoquinone, oxidative stress, SOD, TAC, TBARS, AOPP

\section{Introduction}

$\mathrm{F}$ luoride $\left(\mathrm{F}^{-}\right)$is an essential trace element that, in low concentrations, has been proven to be beneficial for teeth and bone development (Pendrys, 2001).

Fluoride $\left(\mathrm{F}^{-}\right)$anions are widely distributed in the environment in different forms and their compounds are extensively used. Water consumption is typically the largest contributor to daily $\mathrm{F}$ intake either due to runoff of $\mathrm{F}^{-}$-containing rocks and soils into groundwater or artificial fluoridation of drinking water in some areas (ATSDR, 2003).

Furthermore, $\mathrm{F}^{-}$anions are incorporated in various insecticides, fluoridated foodstuff, Teflon-lined cookware (NRC, 2006) and in topical agents (toothpastes, dental varnishes, gels, rinses, tablets, and drops) designed to reduce dental decay. As a result, the consumption of fluoride became uncontrolled and unpredictable often exceeding its therapeutic window, particularly among children (Natalia and Gennadii, 2012).

An excessive fluoride consumption has been linked to development of fluorosis, a slow degenerative diseases, affecting teeth and bone tissues (Sarkar et al., 2014), as well as inducing neurological defects (Malin and Christine, 2015). During recent decades, numerous investigations have established the toxicity of fluoride 
for cells of different tissues both in vitro and in vivo. Oxidative stress has been considered an important mechanism of fluoride intoxication (Barbier et al., 2010).

Thymoquinone (TQ), the main active component of the volatile Nigella sativa (black cumin) seed oil have demonstrated a high antioxidant antiinflammatory and hepatoprotective properties (Mohannad and Peter, 2014).

The goal of present work was to investigate the possible protective effects of thymoquinone, against fluoride-induced hematological and biochemical alterations.

\section{Material and method}

\section{Chemicals and drugs}

Sodium fluoride was purchased from El-Gomhoria Co. for Chemical and Pharmaceutical Products, El-Amirya, Cairo, Egypt. It was in the form of white powder freely soluble in distilled water. Thymoquinone was obtained from Sigma-Aldrich Chemical Co. (St Louis, MO, USA) in the form of $100 \mathrm{mg}$ capsules freely soluble in distilled water.

\section{Animal group deployment}

This study was carried out on 70 adult male albino rats of approximately $200 \pm 50 \mathrm{~g}$ body weight. Animals were obtained from the Medical Research Centre of Faculty of Medicine Ain Shams University. Rats were allowed free access to rat chow diet and water. They were handled in accordance with the standard guide for the use and care of laboratory animals and were divided into 7 equal groups as follows:

- $\quad 1^{\text {st }}$ group (negative control group): Rats were kept without handling to determine basic parameters for 5 weeks.

- 2nd group (positive control group): Rats received distilled water orally for 5 weeks.

- 3rd group (thymoquinone TQ group): Rats received orally TQ at a dose of $10 \mathrm{mg} / \mathrm{kg}$ body weight /day for 5 weeks (After Ali and Bunden, 2003).

- 4th group ( $1^{\text {st }}$ sodium fluoride group): Rats were intoxicated with sodium fluoride orally at a dose of $10 \mathrm{mg} / \mathrm{kg}$ body weight /day for 4 weeks (Blaszczyk et al., 2011).

- 5 th group ( $2^{\text {nd }}$ sodium fluoride group): Rats were intoxicated with sodium fluoride daily for a similar duration but at a dose of $20 \mathrm{mg} / \mathrm{kg}$ body weight /day (Blaszczyk et al, 2012)

- 6th group ( $1^{\text {st }}$ protection group): TQ was given at a dose of $10 \mathrm{mg} / \mathrm{kg}$ body weight/day then followed by both TQ and $\mathrm{Na} F$ at a dose of $10 \mathrm{mg} / \mathrm{kg}$ body weight /day for 4 weeks.

- 7 th group ( $2^{\text {nd }}$ protection group): TQ was given for 1 week then concomitantly with $\mathrm{Na}$ $\mathrm{F}$ at a dose of $20 \mathrm{mg} / \mathrm{kg}$ body weight /day for 4 weeks.

\section{Experimental parameters}

At the end of the experiment period, animals were anaesthetized and sacrificed. Abdominal aorta was exposed. Blood was collected and rapidly divided into $2 / 3$ to be put in a heparinized tube and the other $1 / 3$ was collected in a plain tube.

The heparinized portion was used for the determination of:

a. Hematological parameters $(\mathrm{Hb}, \mathrm{RBC}$, TLC and platelets count) using Beckman Coulter.

b. Oxidative indices

i. Superoxide dismutase (SOD) according to Kakkar et al. (1984)

ii. Total antioxidant capacity (TAC) after the method of Koracevic et al. (2001).

iii. Serum advanced oxidation protein products (AOPP) according to Witko-Sarsat et al. (1996).

iv. Thiobarbituric acid reactive substances (TBARS): Using the method of Hartnett et al. (2000)

The rest was centrifuged at $3000 \mathrm{rpm}$ for 15 min, stored in the deep freeze at $-20^{\circ} \mathrm{C}$ for further biochemical analysis:

- Total cholesterol and triglycerides (TG) after the method of Zollner and Kirsch (1962).

- Blood glucose concentration after Trinder (1969).

- Aspartate aminotransferase (AST) and alanine aminotransferase (ALT) according to Henry et al (1974).

- Alkaline phosphatase (ALT) according to Gowenlock et al. (1988).

- Total serum bilirubin according to Walter and Gerade (1970).

- Total serum proteins according to Lewandrowski and Lewandrowski (2002). 


\section{Statistical analysis}

Numerical data were expressed as mean \pm standard deviation. Data were analyzed using Statistical Package for Social Science (SPSS-Version 17.0) software. Significance between experimental groups were determined using one way analysis of variance (ANOVA) followed by post hoc tests (LSD) for the comparison between each two groups. $\mathrm{P}<0.05$ was considered statistically significant (Snedecor and Cochran, 1973).

\section{Results}

Table (1) shows no significant difference between group I (negative control group), group II (positive control group) and group III (thymoquinone TQ group) as regards the different studied parameters.

Table (2) shows a comparison between group I (negative control group) and the toxic groups (group IV and V) as regards the different experimental parameters. Regarding hematological parameters, a significant decrease of $\mathrm{Hb}$ concentration, RBC, TLC and platelet count was noticed in the toxic groups (group IV and V) compared to the negative control group. Significant increase in serum cholesterol, TG and blood glucose level in addition to liver enzymes and total bilirubin levels were observed in the toxic groups (group IV and V) compared to the negative control group, with significant decrease in total serum proteins in the same groups. Regarding oxidative indices, there was significant increase in TBARS and AOPP in addition to significant decrease in SOD and TAC among group IV and V when compared to negative control group.

Table (3) shows comparison between group I (negative control group) group IV and group VI as regards the different experimental parameters. It was observed that fluoride-induced hematological and biochemical changes were ameliorated in the group that received TQ (group VI) when compared to the toxic group (group IV).

Table (4) shows comparison between group I (negative control group) group $\mathrm{V}$ and group VII as regards the different experimental parameters. Significant differences were noticed between group VII and V when compared with GI and it showed that TQ administration alleviated the toxic effects of $\mathrm{NaF}$ but still not reaching the control level.

Table (1): ANOVA one-way statistical analysis showing comparison between group I (negative control group) group II (positive control group) group III (thymoquinone TQ group) as regards the different experimental parameters. Each group consisted of 10 rats

\begin{tabular}{|c|c|c|c|c|c|}
\hline Group & $\begin{array}{l}\text { Negative control } \\
\text { group (I) }\end{array}$ & $\begin{array}{l}\text { Positive control } \\
\text { group (II) }\end{array}$ & $\begin{array}{l}\text { Thymoquinone TQ } \\
\text { group (III) }\end{array}$ & $\begin{array}{r}\text { Stat } \\
\text { ana }\end{array}$ & $\begin{array}{l}\text { ical } \\
\text { sis }\end{array}$ \\
\hline Parameter & Mean \pm SD & Mean \pm SD & Mean \pm SD & $\mathbf{F}_{\mathbf{c}}$ & LSD \\
\hline $\mathrm{Hb}(\mathrm{g} / \mathrm{dl})$ & $13.7 \pm 1.8$ & $13.5 \pm 1.9$ & $13.6 \pm 1.7$ & 0.304 & - \\
\hline $\mathrm{RBC}$ count $\left(\mathrm{x} 10^{6} / \mathrm{mm}^{3}\right)$ & $5.99 \pm 1.1$ & $5.97 \pm 1.0$ & $5.95 \pm 0.9$ & 0.683 & - \\
\hline Total leucocytic count $\left(\times 10^{3} / \mathrm{mm}^{3}\right)$ & $7.98 \pm 1.0$ & $7.95 \pm 0.8$ & $7.97 \pm 0.91$ & 0.433 & - \\
\hline Platelet count $\left(\mathrm{x} 10^{3} / \mathrm{mm}^{3}\right)$ & $758 \pm 68.9$ & $762 \pm 68.0$ & $757 \pm 60.0$ & 1.2 & - \\
\hline Cholesterol (mg/dl) & $114 \pm 17.5$ & $116 \pm 15.6$ & $115.5 \pm 14$ & 2.3 & - \\
\hline $\mathrm{TG}(\mathrm{mg} / \mathrm{dl})$ & $78.9 \pm 3.3$ & $80.1 \pm 3.5$ & $79.0 \pm 3.2$ & 0.741 & - \\
\hline Glucose concentration (mg/dl) & $86.29 \pm 4.5$ & $85.0 \pm 4.0$ & $84.0 \pm 3.5$ & 1.8 & - \\
\hline AST (IU/L) & $10.52 \pm 1.72$ & $11.0 \pm 1.5$ & $12.0 \pm 1.6$ & 3.11 & - \\
\hline ALT (IU/L) & $35.3 \pm 2.7$ & $34.5 \pm 2.5$ & $33.9 \pm 2.3$ & 31.95 & - \\
\hline ALP (IU/L) & $116.0 \pm 3.8$ & $114.0 \pm 3.5$ & $115.0 \pm 3.4$ & 3.8 & - \\
\hline Total bilirubin (mg/dl) & $1.11 \pm 0.04$ & $1.2 \pm 0.03$ & $0.9 \pm 0.01$ & 1.2 & - \\
\hline TSP (g/dl) & $7.3 \pm 1.3$ & $7.2 \pm 1.2$ & $7.0 \pm 1.1$ & 0.164 & - \\
\hline $\mathrm{SOD}(\mathrm{U} / \mathrm{mg} \mathrm{Hb})$ & $23 \pm 2.87$ & $23.2 \pm 2.20$ & $2.35 \pm 2.10$ & 0.154 & - \\
\hline $\mathrm{TAC}(\mu \mathrm{mol} / \mathrm{L})$ & $2.09 \pm 0.47$ & $2.088 \pm 0.4$ & $2.078 \pm 0.3$ & 0.304 & - \\
\hline $\mathrm{AOPP}(\mu \mathrm{mol} / \mathrm{L})$ & $0.95 \pm 0.02$ & $0.94 \pm 0.01$ & $0.96 \pm 0.03$ & 0.98 & - \\
\hline TBARS (nmol/ml) & $235 \pm 21$ & $234.3 \pm 18$ & $235.3 \pm 19$ & 0.863 & - \\
\hline
\end{tabular}

$S D=$ standard deviation; $F_{c}=$ Variance ratio calculated by ANOVA one-way statistical analysis; $F_{t}($ tabulated $F)$ at level of significance $<0.05=2.24 ;$ LSD =Least significant difference; HB=Hemoglobin concentration; TG = Triglycerides; ALT= alanine aminotransferase; AST= aspartate aminotransferase; ALP = Alkaline phosphatase; TSP

= Total serum protein; $S O D=$ Superoxide dismutase; TAC =Total antioxidant capacity; $A O P P=$ Advanced oxidation protein products; TBARS=Thiobarbituric acid reactive substances. 
Table (2): ANOVA one-way statistical analysis showing comparison between group I (negative control group) group IV and group $V$ as regards the different experimental parameters. Each group consisted of 10 rats

\begin{tabular}{|c|c|c|c|c|c|}
\hline \multirow[b]{2}{*}{ Parameter } & \multirow{2}{*}{$\begin{array}{c}\begin{array}{c}\text { Negative control } \\
\text { group (I) }\end{array} \\
\text { Mean } \pm \text { SD } \\
\end{array}$} & \multirow{2}{*}{$\begin{array}{c}\begin{array}{c}\text { group (IV) } \\
\mathbf{1}^{\text {st }} \text { NaF group }\end{array} \\
\text { Mean } \pm \text { SD } \\
\end{array}$} & \multirow{2}{*}{$\begin{array}{c}\begin{array}{c}\text { group }(V) \\
2^{\text {nd }} \text { NaF group }\end{array} \\
\text { Mean } \pm \text { SD } \\
\end{array}$} & \multicolumn{2}{|c|}{ Statistical analysis } \\
\hline & & & & $\mathbf{F}_{\mathrm{c}}$ & LSD \\
\hline $\mathrm{Hb}(\mathrm{g} / \mathrm{dl})$ & $13.7 \pm 1.8$ & $10.0 \pm 0.9$ & $9.2 \pm 0.7$ & 30.4 & 60.2 \\
\hline $\mathrm{RBC}$ count $\left(\mathrm{x} 10^{6} / \mathrm{mm}^{3}\right)$ & $5.99 \pm 1.1$ & $5.0 \pm 1.0$ & $4.9 \pm 1.2$ & 86.3 & 160.2 \\
\hline Total leucocytic count $\left(\times 10^{3} / \mathrm{mm}^{3}\right)$ & $7.98 \pm 1.0$ & $6.5 \pm 0.02$ & $6.0 \pm 0.01$ & 38.65 & 3.2 \\
\hline Platelet count $\left(\times 10^{3} / \mathrm{mm}^{3}\right)$ & $758 \pm 68.9$ & $402 \pm 60.3$ & $375 \pm 50.0$ & 99.2 & 180.7 \\
\hline Cholesterol (mg/dl) & $114 \pm 17.5$ & $248.5 \pm 6.0$ & $282.2 \pm 6.3$ & 8.421 & 16.9 \\
\hline TG (mg/dl) & $78.9 \pm 3.3$ & $136.7 \pm 4.5$ & $238.6 \pm 5.8$ & 9.409 & 18.6 \\
\hline Glucose concentration $(\mathrm{mg} / \mathrm{dl})$ & $86.29 \pm 4.5$ & $240.0 \pm 9.1$ & $255 \pm 10.3$ & 49.327 & 88.3 \\
\hline AST (IU/L) & $10.52 \pm 1.72$ & $78.0 \pm 6.0$ & $97.0 \pm 9.0$ & 21.8 & 10.7 \\
\hline ALT (IU/L) & $35.3 \pm 2.7$ & $120 \pm 12.0$ & $150.5 \pm 12.8$ & 25.94 & 57.2 \\
\hline ALP (IU/L) & $116.0 \pm 3.8$ & $234.0 \pm 10.0$ & $270 \pm 15.1$ & 10.309 & 16.5 \\
\hline Total bilirubin $(\mathrm{mg} / \mathrm{dl})$ & $1.11 \pm 0.04$ & $1.93 \pm 0.01$ & $1.97 \pm 0.02$ & 5.78 & 3.2 \\
\hline TSP (g/dl) & $7.3 \pm 1.3$ & $4.34 \pm 0.2$ & $4.0 \pm 1.16$ & 19.58 & 21.65 \\
\hline $\mathrm{SOD}(\mathrm{U} / \mathrm{mg} \mathrm{Hb})$ & $23 \pm 2.87$ & $9,61 \pm 1.5$ & $8.0 \pm 1.0$ & 177.1 & 3.2 \\
\hline $\mathrm{TAC}(\mu \mathrm{mol} / \mathrm{L})$ & $2.09 \pm 0.47$ & $1.0 \pm 0.01$ & $0.8 \pm 0.02$ & 45 & 0.5 \\
\hline AOPP $(\mu \mathrm{mol} / \mathrm{L})$ & $0.95 \pm 0.02$ & $1.45 \pm 0.07$ & $1.59 \pm 0.08$ & 8.9 & 0.27 \\
\hline TBARS (nmol/ml) & $235 \pm 21$ & $305 \pm 22.5$ & $320 \pm 23.0$ & 41.829 & 5.2 \\
\hline
\end{tabular}

$S D=$ standard deviation $; F_{c}=$ Variance ratio calculated by ANOVA one -way statistical analysis; $F_{t}($ tabulated $F)$ at level of significance $<0.05=3.23 ; L S D=$ Least significant difference; $H B=$ Hemoglobin concentration; TG= Triglycerides; $A L T=$ Alanine aminotransferase; $A S T=$ Aspartate aminotransferase; $A L P=$ Alkaline phosphatase; $T S P=$ Total serum protein; $S O D=$ Superoxide dismutase; TAC = Total antioxidant capacity; AOPP= Advanced oxidation protein products; TBARS= Thiobarbituric acid reactive substances.

Table (3): ANOVA one-way statistical analysis showing comparison between group I (negative control group) group IV and group VI as regards the different experimental parameters. Each group consisted of 10 rats

\begin{tabular}{|c|c|c|c|c|c|}
\hline \multirow[b]{2}{*}{ Parameter } & \multirow{2}{*}{$\begin{array}{c}\begin{array}{c}\text { Negative control } \\
\text { group (I) }\end{array} \\
\text { Mean } \pm \text { SD }\end{array}$} & \multirow{2}{*}{$\begin{array}{c}\operatorname{group}(\mathrm{IV}) 1^{\text {st }} \\
\text { NaF group } \\
\text { Mean } \pm \text { SD }\end{array}$} & \multirow{2}{*}{$\begin{array}{c}\begin{array}{c}\text { group (VI) } \\
1^{\text {st }} \text { protection group }\end{array} \\
\text { Mean } \pm \text { SD }\end{array}$} & \multicolumn{2}{|c|}{$\begin{array}{c}\text { Statistical } \\
\text { analysis }\end{array}$} \\
\hline & & & & $\mathbf{F}_{\mathrm{c}}$ & LSD \\
\hline $\mathrm{Hb}(\mathrm{g} / \mathrm{dl})$ & $13.7 \pm 1.8$ & $10.0 \pm 0.9$ & $13.0 \pm 1.3$ & 149 & 0.5 \\
\hline RBC count $\left(\times 10^{6} / \mathrm{mm}^{3}\right)$ & $5.99 \pm 1.1$ & $5.0 \pm 1.0$ & $5.65 \pm 1.0$ & 46.6 & 0.4 \\
\hline Total leucocytic count $\left(\times 10^{3} / \mathrm{mm}^{3}\right)$ & $7.98 \pm 1.0$ & $6.5 \pm 0.02$ & $7.5 \pm 0.9$ & 675.9 & 64.4 \\
\hline Platelet count $\left(\times 10^{3} / \mathrm{mm}^{3}\right)$ & $758 \pm 68.9$ & $402 \pm 60.3$ & $699 \pm 50.5$ & 134.5 & 11.0 \\
\hline Cholesterol (mg/dl) & $114 \pm 17.5$ & $248.5 \pm 6.0$ & $199.5 \pm 5.9$ & 18.19 & 9.5 \\
\hline TG (mg/dl) & $78.9 \pm 3.3$ & $136.7 \pm 4.5$ & $102.5 \pm 4.5$ & 16.59 & 8.2 \\
\hline Glucose concentration $(\mathrm{mg} / \mathrm{dl})$ & $86.29 \pm 4.5$ & $240.0 \pm 9.1$ & $118.5 \pm 10.5$ & 20.715 & 9.5 \\
\hline AST (IU/L) & $10.52 \pm 1.72$ & $78.0 \pm 6.0$ & $11.86 \pm 2.2$ & 39.9 & 3.7 \\
\hline $\operatorname{ALT}(\mathrm{IU} / \mathrm{L})$ & $35.3 \pm 2.7$ & $120 \pm 12.0$ & $82.6 \pm 9.5$ & 46.09 & 5.2 \\
\hline ALP (IU/L) & $116.0 \pm 3.8$ & $234.0 \pm 10.0$ & $190 \pm 8.8$ & 22.71 & 3.2 \\
\hline Total bilirubin $(\mathrm{mg} / \mathrm{dl})$ & $1.11 \pm 0.04$ & $1.93 \pm 0.01$ & $1.4 \pm 0.02$ & 45.0 & 0.5 \\
\hline TSP (g/dl) & $7.3 \pm 1.3$ & $4.34 \pm 0.2$ & $6.5 \pm 1.2$ & 49.0 & 0.33 \\
\hline $\mathrm{SOD}(\mathrm{U} / \mathrm{mg} \mathrm{Hb})$ & $23 \pm 2.87$ & $9,61 \pm 1.5$ & $18.3 \pm 0.83$ & 213.5 & 5.6 \\
\hline $\mathrm{TAC}(\mu \mathrm{mol} / \mathrm{L})$ & $2.09 \pm 0.47$ & $1.0 \pm 0.01$ & $2.0 \pm 0.3$ & 35.0 & 5.05 \\
\hline $\mathrm{AOPP}(\mu \mathrm{mol} / \mathrm{L})$ & $0.95 \pm 0.02$ & $1.45 \pm 0.07$ & $1.1 \pm 0.03$ & 18.5 & 2.7 \\
\hline TBARS $(\mathrm{nmol} / \mathrm{ml})$ & $235 \pm 21$ & $305 \pm 22.5$ & $299 \pm 23.3$ & 55.9 & 10.5 \\
\hline
\end{tabular}

$S D=$ standard deviation; $F_{c}=$ Variance ratio calculated by ANOVA one-way statistical analysis; $F_{t}$ (tabulated $\left.F\right)$ at level of significance $<0.05=3.39 ; \quad L S D=$ Least significant difference; $H B=$ Hemoglobin concentration; TG= Triglycerides; $A L T=$ Alanine aminotransferase; $A S T=$ Aspartate aminotransferase; $A L P=$ Alkaline phosphatase; TSP= Total serum protein; $S O D=$ Superoxide dismutase; TAC = Total antioxidant capacity; AOPP= Advanced oxidation protein products; TBARS=Thiobarbituric acid reactive substances. 
Table (4): ANOVA one-way statistical analysis showing comparison between group I (negative control group) group V and group VII as regards the different experimental parameters. Each group consisted of 10 rats

\begin{tabular}{|l|c|c|c|c|c|}
\hline \multirow{2}{*}{ Parameter } & $\begin{array}{c}\text { Gegative control } \\
\text { group (I) }\end{array}$ & $\begin{array}{c}\text { group (V) } \\
\mathbf{2}^{\text {nd }} \text { NaF group }\end{array}$ & $\begin{array}{c}\text { group (VII) 2 } \\
\text { protection group }\end{array}$ & \multicolumn{2}{c|}{$\begin{array}{c}\text { Statistical } \\
\text { analysis }\end{array}$} \\
\cline { 2 - 6 } & Mean \pm SD & Mean \pm SD & Mean \pm SD & F $_{\mathbf{c}}$ & LSD \\
\hline $\mathrm{Hb}(\mathrm{g} / \mathrm{dl})$ & $13.7 \pm 1.8$ & $9.2 \pm 0.7$ & $12.0 \pm 1.2$ & 129 & 50.5 \\
\hline RBC count $\left(\mathrm{x} 10^{6} / \mathrm{mm}^{3}\right)$ & $5.99 \pm 1.1$ & $4.9 \pm 1.2$ & $5.0 \pm 0.3$ & 76.5 & 40.0 \\
\hline Total leucocytic count $\left(\mathrm{x} 10^{3} / \mathrm{mm}^{3}\right)$ & $7.98 \pm 1.0$ & $6.0 \pm 0.01$ & $7.0 \pm 0.6$ & 575.5 & 44.8 \\
\hline Platelet count $\left(\mathrm{x} 10^{3} / \mathrm{mm}^{3}\right)$ & $758 \pm 68.9$ & $375 \pm 50.0$ & $650 \pm 52.3$ & 132.3 & 9.5 \\
\hline Cholesterol $(\mathrm{mg} / \mathrm{dl})$ & $114 \pm 17.5$ & $282.2 \pm 6.3$ & $180 \pm 5.3$ & 38.9 & 19.0 \\
\hline TG $(\mathrm{mg} / \mathrm{dl})$ & $78.9 \pm 3.3$ & $238.6 \pm 5.8$ & $135 \pm 3.2$ & 65.9 & 17.3 \\
\hline Glucose concentration $(\mathrm{mg} / \mathrm{dl})$ & $86.29 \pm 4.5$ & $255 \pm 10.3$ & $125 \pm 4.9$ & 43.5 & 55.0 \\
\hline AST $(\mathrm{IU} / \mathrm{L})$ & $10.52 \pm 1.72$ & $97.0 \pm 9.0$ & $30.5 \pm 2.0$ & 29.2 & 7.3 \\
\hline ALT $(\mathrm{IU} / \mathrm{L})$ & $35.3 \pm 2.7$ & $150.5 \pm 12.8$ & $55.6 \pm 3.1$ & 14.9 & 2.5 \\
\hline ALP $(\mathrm{IU} / \mathrm{L})$ & $116.0 \pm 3.8$ & $270 \pm 15.1$ & $139 \pm 3.0$ & 26.9 & 3.7 \\
\hline Total bilirubin $(\mathrm{mg} / \mathrm{dl})$ & $1.11 \pm 0.04$ & $1.97 \pm 0.02$ & $1.4 \pm 0.01$ & 57.0 & 5.3 \\
\hline TSP $(\mathrm{g} / \mathrm{dl})$ & $7.3 \pm 1.3$ & $4.0 \pm 1.16$ & $6.3 \pm 0.9$ & 94.0 & 3.9 \\
\hline SOD $(\mathrm{U} / \mathrm{mg} \mathrm{Hb})$ & $23 \pm 2.87$ & $8.0 \pm 1.0$ & $20.5 \pm 0.9$ & 65.5 & 12.3 \\
\hline TAC $(\mu \mathrm{mol} / \mathrm{L})$ & $2.09 \pm 0.47$ & $0.8 \pm 0.02$ & $1.9 \pm 0.01$ & 76.9 & 16.9 \\
\hline AOPP $(\mu \mathrm{mol} / \mathrm{L})$ & $0.95 \pm 0.02$ & $1.59 \pm 0.08$ & $1.2 \pm 0.13$ & 45.3 & 2.294 \\
\hline TBARS $(\mathrm{nmol} / \mathrm{ml})$ & $235 \pm 21$ & $320 \pm 23.0$ & $261 \pm 2.0$ & 12.8 & 0.11 \\
\hline
\end{tabular}

$S D=$ standard deviation; $F_{c}=$ Variance ratio calculated by ANOVA one -way statistical analysis; $F_{t}$ (tabulated $\left.F\right)$ at level of significance $<0.05=3.23 ;=$ statistically significant; LSD= Least significant difference; HB= Hemoglobin concentration; $T G=$ Triglycerides; ALT=Alanine aminotransferase; AST=Aspartate aminotransferase; ALP=Alkaline phosphatase; $T S P=$ Total serum protein; $S O D=$ Superoxide dismutase; $T A C=$ Total antioxidant capacity; AOPP= Advanced oxidation protein products; TBARS=Thiobarbituric acid reactive substances.

\section{Discussion}

Sufficient evidence had demonstrated that fluoride produced deleterious effects in skeletal, dental and soft tissues. Numerous studies linked increased oxidative stress to F exposure (Grucka-Mamczar et al., 2009; Nabavi et al., 2013).

Natural herbal constituents are extensively studied for their ability to protect cells from miscellaneous damages. Currently, the use of phytochemicals as a therapy in diseases related to oxidative stress has gained immense interest for their ability to quench free radicals and their capability to protect body tissues against oxidative stress (Nabavi et al., 2012). The present study was an attempt to evaluate the toxic effect of sodium fluoride and the possible ameliorative role of thymoquinone, the major bioactive constituent of $\mathrm{N}$. sativa seed.

Under normal circumstances, the potential damaging effects of free radicals are limited by the endogenous antioxidant defenses in body (Gey, 1998). Several enzymes are important as cellular antioxidative defense specially superoxide dismutase (SOD) which serves a key role against superoxide, one of the main reactive oxygen species in the cell. Protective antioxidant pathways also include endogenous free radical scavengers (albumin, urate, and bilirubin) and metal-preventive antioxidants (caeruloplasmin and transferrin) (Miller et al., 1993; Jackson et al., 2002).

The measure of TAC generally considers the cumulative action of all the antioxidants present in plasma and body fluids, thus provides an integrated parameter rather than the simple sum of measurable antioxidants (Ghiselli et al., 2000). In the present study, exposure to sodium fluoride depleted SOD antioxidant enzyme and decreased total antioxidant capacity (TAC) suggesting an impaired function of antioxidant defense system.

An ability of oxidative stress to provoke cell death has been associated with oxidative damage to macromolecules such as DNA and proteins, peroxidation of membrane phospholipids, and mitochondrial depolarization, thus initiating apoptosis and organ lesions (Halliwell and Guttteridge, 2007).

In the present study increased TBARS may reflect $\mathrm{F}^{-}$-induced lipid peroxidation. Lipid peroxidation is the process of oxidative degradation of membrane lipids especially polyunsaturated fatty acids, resulting in their damage and impairment of a variety of intra- and extramitochondrial membrane transport systems thus contributing to apoptosis (Agalakova and Gusev, 2012).

In the current study, AOPP was significantly increased in $\mathrm{NaF}$ treated groups. Advanced oxidation protein product (AOPP) have been defined as a novel marker of oxidative stress-mediated protein damage. Oxidation of amino acid residues such as tyrosine, which leads to the formation of dityrosine, protein aggregation, cross-linking, and fragmentation are but a few examples of ROS-mediated protein damage (Inkielewicz-Stępniak and Knap, 2012). The increased AOPP in addition to a concomitant increase in TBARS, can serve as an indicator for the intensity of fluoride-associated oxidative stress. This in turn may suggest another important indirect mechanism of fluoride-induced cytotoxicity by supporting the relationship between endogenous antioxidant system and oxidative stress in the pathogenesis of toxicity. 
The findings reported here are consistent with those of others in showing that, in $\mathrm{F}^{-}$-treated rats, the combined effect of reductions in antioxidant enzyme activity plus high levels of lipid peroxidation is associated with deleterious oxidative changes due to the accumulation of toxic products (InkielewiczStępniak et al., 2012 and Sarkar et al., 2014).

Therefore, enhancing endogenous antioxidant status by administrating exogenous compounds can provide an effective strategy to prevent and reverse NaF-induced toxicity (Wessam, 2013).

In the present work, supplementation of $\mathrm{NaF}$ intoxicated groups with TQ, restored antioxidative homeostasis. This was evidenced by increased assayed markers of endogenous antioxidant system (SOD and TAC) with concomitant decrease of markers of oxidative stress mediated damage (TBARS and AOPP).

The beneficial protective antioxidant activity of TQ in vivo, has been previously reported and may be attributed to the ability of TQ to act as a free radical and superoxide radical scavenger, as well as preserving the activity of various anti-oxidant enzymes (Woo et al., 2012 and Hamid and Hossein, 2014).

Studies have also shown that TQ could up regulate the glutathione-S-transferase(GST), glutathione peroxidase (GPx) and catalase (CAT) genes with the consequent elevation of hepatic GST, GPx and CAT levels to overcome oxidative stress (Nagi and Almakki, 2009; Ismail et al., 2010). The strong antioxidant properties of TQ may be related to the redox properties of the quinine structure of the TQ molecule, and its unrestricted crossing of morphological barriers, thus gaining easy access to sub cellular compartments and facilitating the ROS scavenging effect (Badary et al., 2003; Alenzi et al., 2013).

Regarding the effect of sodium fluoride on the measured hematological parameters, a significant decrease of $\mathrm{Hb}$ concentration, RBC, TLC and platelet count was noticed in the toxic groups compared with controls. Similar results have been reported by Vijaya Bhaskara Rao and Vidyunmala (2009) and Sharma et al (2013).

Various authors suggested that fluoride toxicity has potential harming effects on bone marrow, hematopoietic organs and hematopoietic progenitor cells (Machalinski et al., 2000). Deng et al (2013) also concluded that dietary $\mathrm{F}^{-}$could significantly cause anemia and impair the integrity of erythrocyte membrane, the transport capacity of oxygen and carbon dioxide, and erythrocyte immune adherence function. This was linked to the ability of $\mathrm{F}^{-}$to trigger irreversible damage to erythrocytes leading to apoptosis or necrosis. Underlying mechanisms in the development of $\mathrm{F}^{-}$induced apoptosis include accumulation of free cytosolic $\mathrm{Ca}^{2+}$ as a major pathophysiological process, in addition to ATP depletion, and oxidative stress (Agalakova and Gusev, 2011). Moreover, the noted decrease in TLC can be attributed to destruction of the ultrastructure of the thymus in addition to DNA damage in the thymus, bone marrow, and blood lymphocytes (Zhao et al., 2014)

In the present study, it was observed that fluoride-induced hematological changes were ameliorated in the groups that received TQ compared to toxic groups. These results suggest a beneficial effect of TQ against fluoride-induced changes in bone marrow and hematopoietic progenitor cells.

Similar results were observed by Toghyani et al. (2010) who noted significant increase in RBC count, hemoglobin concentration and hematocrite value in addition to increased weight of lymphoid organs. On the other hand Asgary et al. (2012) denied any direct effect of nigella sativa on blood cells.

In the current study, the administration of sodium fluoride led to significant increases in serum cholesterol, and triglycerides when compared with the control groups. $\mathrm{NaF}$-induced changes in lipid profile are in accordance with the obtained results by Al-Harbi (2014) and Khudair and Aldabaj (2014). Conflicting results were also obtained by Kanbur et al. (2009) who reported lowering in plasma cholesterol and TG levels following the administration of sodium fluoride.

It was suggested that the abnormal enzyme activities seem to be one of the chief factors responsible for the rise in serum triglycerides and cholesterol. Enzymes inhibited by fluoride, such as triglyceride lipase, unspecific esterase and pyrophosphates may be involved, causing inhibition of fatty acids oxidation. Besides, fluoride was found to cause hypercholesterolemia due to lowering of insulin level (Garcia-Montalvo et al., 2009).

Moreover, oxidative stress induced by $\mathrm{NaF}$ could be claimed. It was suggested that $\mathrm{NaF}$ intoxication causes increased lipid peroxidation and loss of membrane integrity which might be important in altered lipid metabolism and closely associated with the observed hyperlipidemia (Abdel-Wahab, 2013).

Thymoquinone supplementation alleviated the previously mentioned alteration in the lipid profile. There is some scientific evidence of a hypolipidemic effect of TQ; however, the mechanism of this hypolipidemic action is not fully understood (Badary et al., 2000; Bamosa et al., 2002). Decreased cholesterol synthesis by TQ, and more importantly, its antioxidant role have been proposed (Pourghassem-Gargari et al., 2009).

A significant increase in serum blood glucose level was found in $\mathrm{F}^{-}$exposed rats. Results of the current study coincide with results from other studies by Chehoud et al. (2008) Inhibition of enzymes in glycolytic pathway (hexokinase, enolase, pyruvate kinase) by fluoride was proposed as one of the reasons for increased glucose in blood by fluoride (Bergandi et al., 2010). However, the primary mechanism appears to involve decreased insulin secretion and transcription in pancreatic beta cells (Garcia-Montalvo et al, 2009)

The current results showed that TQ administration blunted the hyperglycemia induced by $\mathrm{NaF}$. Interesting studies have confirmed that treatment with TQ have an antidiabetic action through extrapancreatic activities with activation of cell signaling molecules and not through affecting insulin 
release. The hypoglycemic effect of TQ has been also suggested to be due to its ability to decrease hepatic gluconeogenesis, to preserve pancreatic beta-cell integrity, and to increase antioxidant defense system activity (Fararh et al., 2002 and Rchid et al., 2004). Abdullah (2015) stated that the mechanism of N. sativa hypoglycemic effect is multifactorial including increasing insulin release, decreasing insulin resistance, stimulating $\beta$-cell activity and decreasing intestinal glucose absorption.

Findings of the present study showed that oral administration of $\mathrm{NaF}$ induced a significant increase in serum liver enzymes namely AST, ALT, and ALP and total bilirubin. These indices usually reflect hepatocyte integrity and cholestasis and their elevation indicates hepatocellular damage (Pratt and Kaplan, 2005)

Additionally, a significant decrease in total serum proteins was noted in $\mathrm{NaF}$ intoxicated groups. The change in serum protein may reflect a decrease in the liver functioning mass and can be employed for monitoring liver synthetic activity, since all blood proteins are synthesized in the liver except for gamma globulins (Dabrowska et al., 2006).

The significant alteration of liver function indices in the present study is in accordance with studies demonstrating the induction of both pathomorphological and metabolic changes in the liver by exposure to fluoride (AL-Harbi et al., 2014; Atmaca et al., 2014).

As a site of active metabolism, the liver can be especially susceptible to fluoride toxicity (Shashi and Thapar, 2001). NaF-induced cytotoxicity and necrotic death of hepatocytes can be related to toxic fluoride effects ultimately leading to cell death. These cellular events include an induction of inflammatory reactions, inhibition of protein synthesis and cell cycle progression, oxidative stress, and DNA damage. The molecular mechanisms underlying fluoride-induced apoptosis include the stimulation of $G$ proteindependent signaling systems, oxidative stress, ATP depletion, activation of the cell surface death receptors, disruption of outer mitochondria membrane, alterations in the ratio of anti-apoptotic-apoptotic Bcl-2 proteins, upregulation of p53 expression, expression of apoptosis-related genes, endoplasmic reticulum stress and disturbances in protein synthesis (Ghosh et al., 2008; Agalakova and Gusev, 2013).

Compared to fluoride alone -treated groups, TQ co-administered groups showed statistically significant difference in the level of serum biomarkers related to hepatic dysfunction (including AST ,ALT, ALP, total bilirubin and total protein) suggesting a potential protective role of TQ against NaF-induced hepatic damage.

Results of our study are in agreement with earlier studies by Daba and Abdel-Rahman (1998) and Yong et al. (2015) suggesting that TQ supplementation could alleviate hepatic toxicity. This protective effect may be due to the ability of TQ to antagonize the enhanced LPO and in turn stabilize the integrity of the cellular membranes leading to preventing or at least decreasing the leakage of liver enzymes.
Farag et al. (2015) concluded that kidney and liver injury due to cyclosporine can be significantly decreased by thymoquinone which resets oxidant / antioxidant balance of the affected organ through scavenging the free radicals.

\section{Conclusion}

Administration of $\mathrm{NaF}$ caused haematological and biochemical alternations. Oxidative stress is considered one of the main contributors to these changes. Supplementation of $\mathrm{NaF}$ intoxicated rats with $\mathrm{TQ}$ ameliorated these effects.

\section{Recommendations}

Further studies to investigate the effect of other $\mathrm{F}^{-}$salts on other body organs and to explore the role of other compounds having free radical scavenging capabilities are recommended.

\section{References}

Abdel-Wahab W (2013): Protective effects of thymoquinone on sodium fluoride-induced hepatotoxicity and oxidative stress in rats. $\mathrm{J}$ Basic Appl. Zool; (66): 263-270.

Abdullah O (2015): A review on the hypoglycemic effect of Nigella Sativa and thymoquinone. Saudi J of medicine and Medical Sciences; 3 (1): 2-7.

Agalakova N and Gusev G (2011): Fluoride-induced death of rat erythrocytes in vitro. Toxicology in Vitro; 25(8): 1609-1618.

Agalakova N and Gusev G (2012): Molecular Mechanisms of Cytotoxicity and Apoptosis Induced by Inorganic Fluoride. International Scholarly Research Network ISRN Cell Biology; Volume 2012, Article ID 403835, 16 pages doi:10.5402/2012/403835

Agalakova N and Gusev G (2013): Excessive fluoride consumption leads to accelerated death of erythrocytes and anemia in rats. Biol Trace Elem Res; 153(1-3):340-9.

Alenzi F, Altamimi M, Kujan O et al (2013): Antioxidant Properties of Nigella sativa. J Mol Genet Med; 7:3-4

Al-Harbi M, Hamza R and Afaf A (2014): Hyperlipidemic and oxidative stress effects of sodium fluoride and the ameliorative role of selenium and curcumin in male mice. Journal of Chemical and Pharmaceutical Research; 6(4):984-998

Ali B and Bunden G (2003): Pharmacological and toxicological properties of Nigella sativa. Phytother Res; 17: 299-305.

Asgary S, Najai S, Ghannadi A, et al (2012): Efficiency of black cumin seeds on hematological factors in normal and hypercholestrolemic rabbits. ARYA Atheroscler; 7(4):146-150

Atmaca N, Atmaca H, Kanici A, et al (2014): Protective effect of resveratrol on sodium fluoride-induced oxidativestress, 
hepatotoxicity and neurotoxicity in rats. Food and Chemical Toxicology; 70: 191-197.

ATSDR (Agency for Toxic Substances and Disease Registry) (2003): Toxicological Profile for Fluorides, Hydrogen Fluoride, and Fluorine. Public Health Service, US Department of Health and Human Services, Atlanta, Georgia.

Badary O, Abdel-Naim A, Abdel-Wahab $\mathrm{M}$ and Hamada F (2000): The influence of thymoquinone on doxorubicin-induced hyperlipidemic nephropathy in rats. Toxicol; 143 (3): 219-26.

Badary O, Taha R, Gamal El-Din A and Abdel-Wahab M (2003): Thymoquinone is a potent superoxide anion scavenger. Drug Chem Toxicol; 26: 87-98.

Bamosa A, Ali B and Al-Hawsawi Z (2002): The effect of thymoquinone on blood lipids in rats. Indian Journal of Physiology and Pharmacology; 46(2):195-201.

Barbier O, Arreola-Mendoza L and Del Razo L (2010): Molecular mechanisms of fluoride toxicity. Chemico-Biological Interactions; 188: 319333.

Bergandi L, Aina V, Garetto S, et al. (2010): Fluoridecontaining bioactive glasses inhibit pentose phosphate oxidative pathway and glucose 6phosphate dehydrogenase activity in human osteoblasts. Chem Biol Int; 183: 405-415.

Blaszczyk I, Birkner E and Kasperczyk S (2011): Influence of methionine on toxicity of fluoride in the liver of rats. Biol Trace Elem Res; 139: $325-331$.

Blaszczyk I, Birkner E, Gutowska I et al. (2012): Influence of methionine and vitamin $\mathrm{E}$ on fluoride concentration in bones and teeth of rats exposed to sodium fluoride in drinking water. Biol Trace Elem Res; 146(3): 335-339.

Chehoud K, Chiba F, Sassaki K, et al (2008): Effects of fluoride intake on insulin sensitivity and insulin signal transduction. Fluoride; 41(4):270-275

Daba $M$ and Abdel-Rahman M (1998): Hepatoprotective activity of thymoquinone in isolated rat hepatocytes. Toxicol Lett; 95: 2329

Dabrowska E, Letko R and Balunowska M (2006): Effect of sodium fluoride on the morphological picture of the rat liver exposed to NaF in drinking water. Adv Med Sci; 51(1): 91-95.

Deng Y, Cui H, Peng X et al. (2013): Effects of high Dietary fluorine on erythrocytes and erythrocyte immune adherence function in broiler chickens. Biol Trace Elem Res; 155(2):247-52.

Farag M, Ahmed G, Shehata R and Kazem A (2015): Thymoquinone improves the kidney and liver changes induced by chronic cyclosporine A treatment and acute renal ischaemia/reperfusion in rats .Journal of Pharmacy and Pharmacology; DOI: 10.1111/jphp. 12363
Fararh K, Atoji Y, Shimizu Y and Takewaki T (2002): Insulinotropic properties of Nigella sativa oil in Streptozotocin plus Nicotinamide diabetic hamster. Res Vet Sci; 73: 279-282.

Garcia-Montalvo E, Reyes-Perez H and Del Razo L (2009): Fluoride exposure impairs glucose tolerance via decreased insulin expression and oxidative stress. Toxicology; 263: 75-83.

Gey K (1998): Vitamins E plus C and interacting conutrients required for optimal health. BioFactors; 7: 113-174.

Ghiselli A, Serafini M, Natella F, et al. (2000): Total antioxidant capacity as a tool to assess redox status: Critical view and experimental data. Free Radical Biology and Medicine; 29(11): 1106-1114.

Ghosh J, Das J, Manna P and Sil P (2008): Cytoprotective effect of arjunolic acid in response to sodium fluoride mediated oxidative stress and cell death via necrotic pathway. Toxicol. In Vitro; 22:1918-1926.

Gowenlock A, McMurry J and McLauchen D (1988): Practical Biochemistry. Heinemann medical Book. Varley, London; p: 719-720.

Grucka-Mamczar E, Zalejska-Fiolka J, Chlubek D, et al (2009): Influence of $\mathrm{NaF}$ and caffeine on the activity of antioxidative enzymes and the concentration of MDA in rat liver. Research report Fluoride; 42(2):105-109.

Halliwell B and Guttteridge J (2007): Free Radicals in Biology and Medicine. 2nd ed. Oxford: Oxford University Press (Clarendon).

Hamid M and Hossein H (2014): The protective effect of Nigella sativa against liver injury: A review. Iranian Journal of Basic Medical Science; 17(12):958-966.

Hartnett M, Stratton R, Browne R, et al. (2000): Serum markers of oxidative stress and severity of diabetic retinopathy. Diabetes; 23(2): 234240.

Henry R, Cannon D and Winkleman J (1974): Clinical Chemistry: Principles and techniques. Harper and Row, New York, p: 60-65.

Inkielewicz-Stępniak I and Knap N (2012): Effect of exposure to fluoride and acetaminophen on oxidative/nitrosative status of liver and kidney in male and female rats. Pharmacological Reports; 64(4):902-911.

Inkielewicz-Stepniak I, Radomski $\mathrm{M}$ and Wozniak $\mathrm{M}$ (2012): Fisetin prevents fluoride- and dexamethasone-induced oxidative damage in osteoblast and hippocampal cells. Food Chem Toxicol; 50:583-589

Ismail M, Al-Naqeep G and Chan K (2010): Nigella sativa thymoquinone-rich fraction greatly improves plasma antioxidant capacity and expression of antioxidant genes in hypercholesterolemic rats. Free Radical Biology and Medicine; 48(5):664-672.

Jackson M, Papa S, Bolanos J, et al. (2002): Antioxidants, reactive oxygen and nitrogen species, gene induction and mitochondrial 
function. Molecular Aspects of Medicine; 23: 209-285.

Kakkar P, Das B and Viswanathan P (1984): A modified spectrophotometric assay of superoxide dismutase. Ind $\mathrm{J}$ Biochem Biophys; 21:130-132

Kanbur M, Eraslan G, Silici S, et al. (2009): Effects of sodium fluoride exposure on some biochemical parameters in mice: Evaluation of the ameliorative effect of royal jelly applications on these parameters. Food Chem Toxicol; 47:1184-9.

Khudair K and Aldabaj A (2014): Effect of High Concentration of Sodium Fluoride on Serum Lipid Profile of Male Rabbits: Hypolipidemic Effect of Grape Seed Oil. Online International Interdisciplinary Research Journal; $\{\mathrm{Bi}-$ Monthly\}, ISSN2249-9598, Volume-IV, Special Issue.

Koracevic D, Koracevic G, Djordjevic S, et al. (2001): Method of the measurement of antioxidant activity in human fluids. J Clin Pathol; 54:356-361

Lewandrowski E and Lewandrowski K (2002): Total serum proteins. In: Clinical Laboratory Medicine, $2^{\text {nd }}$ edition, McClatchy KD (ed.), Williams and Wilkins, London, p: 239-258.

Machalinski B, Zejmo M, Stecewicz I, et al. (2000): The influence of sodium fluoride on the clonogeneclty of human hematopoietic progenitor cells: Preliminary report. Fluoride; 33(4):168-173.

Malin A and Christine T (2015): Exposure to fluoridated water and attention deficit hyperactivity disorder prevalence among children and adolescents in United States: An ecological association. Environmental Health; 14(17): doi:10.1186/s12940-015-003-1.

Miller N, Rice-Evans C, Davies M, et al. (1993): A novel method for measuring antioxidant capacity and its application to monitoring the antioxidant status in premature neonates. Clinical Science; 84(4):407-412.

Mohannad K and Peter M (2014): Thymoquinone: An emerging natural drug with a wide range of medical applications. Iranian Journal of Basic Medical Science; 17(12):950-957.

Nabavi S, Nabavi S and Habtemariam S (2013): Hepatoprotective effect of gallic acid isolated from Peltiphyllumpeltatum against sodium fluoride-induced oxidative stress in rat kidney. Mol Cell Bioch; 372(1-2):233-239.

Nabavi S, Nabavi S, Eslami S and Moghaddam A (2012): In vivo protective effects of quercetin against sodium fluoride-induced oxidative stress in the hepatic tissue. Food Chem; 132: 931-935.

Nagi M and Almakki H (2009): Thymoquinone supplementation induces quinone reductase and glutathione transferase in mice liver: Possible role in protection against chemical carcinogenesis and toxicity. Phytother Res; 23: $1295-1298$.
Natalia I and Gennadii P (2012): Molecular mechanisms of cytotoxicity and apoptosis induced by inorganic fluoride. ISRN Cell Biology; Volume 2012; Article ID 403835.

NRC (National Research Council) (2006): Fluoride in Drinking-Water. A scientific review of EPA's standards, Washington.

Pendrys D (2001): Fluoride ingestion and oral health. Nutrition; 17(11-12): 979-980.

Pourghassem-Gargari B, Ebrahimzadeh-Attary V, Rafraf M, et al. (2009): Effect of dietary supplementation with Nigella sativa L. on serum lipid profile, lipid peroxidation and antioxidant defense system in hyperlipidemic rabbits. Journal of Medicinal Plants Research; 3(10): 815-821.

Pratt D and Kaplan M (2005): Evaluation of liver function. In: Harrison's principles of internal medicine. Braunwald E, Fauci AS, Kasper DL, Hauser SL, Longo DL, Jameson JL (eds.), $16^{\text {th }}$ ed., McGraw-Hill, New York, pp: 1711-171.

Rchid H, Chevassus H, Nmila R, Guiral C, Petit P, et al. (2004): Nigella sativa seed extracts enhance glucose-induced insulin release from rat-isolated Langerhans islets. Fundam Clin Pharmacol; 18: 525-529.

Sarkar C, Das N, Pal S and Dinda B (2014): Oxidative stress induced alteration of protein and nucleic acid metabolism in fluoride intoxicated rat brain. Protection by $3 \alpha$-hydroxy oleanolic acid isolated from Neonatis Wightiana. IJPSR; 5 (7):3047-3066.

Sharma S, Yadav N, Pandey A, et al. (2013): Antioxidant rich diet supplements (Spirulina and tamarind fruit pulp) mitigate hematological disorders in fluoride exposed mice. Toxicological and Environmental Chemistry; 95(10): 1739-1747.

Shashi A and Thapar S (2001): Histopathology of fluoride-induced hepatotoxicity in rabbits. Fluoride; 34(1):34-42.

Snedecor G and Cochran W (1973): Statistical Methods, $6^{\text {th }}$ ed., Ames, Iowa: Iowa State University Press, p: 59.

Toghyani M, Tohidi M, Gheisari A and Tabeidian S (2010): Performance, immunity, serum biochemical and hematological parameters in broiler chicks fed dietary thyme as alternative for an antibiotic growth promote. Afr J Biotechnol; 9(40):6819-6825

Trinder P (1969): Determination of blood glucose using glucose oxidase with an alternative oxygen acceptor. Ann Clin Biochem; 6: 2427.

Vijaya Bhaskara Rao A and Vidyunmala S (2009): Cumulative effect of fluoride on hematological indices of mice, Mus norvegicus albinus. American-Eurasian $\mathrm{J}$ of Toxicol Sci; 1(2):81-3.

Walter M and Gerade H (1970): Bilirubin assay. Microchem J; 15:231-236.

Wessam M (2013): Protective effect of thymoquinone on sodium fluoride-induced hepatotoxicity 
and oxidative stress in rats. The Journal of Basic and Applied Zoology; 66(5):263-270.

Witko-Sarsat V, Nguyen-Khoa T, Jungers T, et al.

(1996): Advanced oxidation protein products as a novel molecular basis of oxidative stress in uremia. Nephrol Dial Transplant; 14 (1):7678.

Woo C, Kumar A, Sethi G and Tan K (2012): Thymoquinone: Potential cure for inflammatory disorders and cancer. Biochem Pharmacol; 83: 443-451.

Yong Y, Ting B, Peng S, et al. (2015): Thymoquinone, a bioactive component of Nigella sativa Linn seeds or traditional spice, attenuates acute hepatic failure and blocks apoptosis via the MAPK signaling pathway in mice. RSC Advances; 5:7285-7290.

Zhao J, Wang H, Tian E, et al. (2014): Toxic effects of fluoride on primary lymphoid organs and white blood cells in female mice. Fluoride; 47(3)227-234.

Zollner N and Kirsch K (1962): Absorptimetric determination of total lipids in serum. Z Ges Exp Med; 135: 544-549.

\section{الملخص العربى}

التخفيف من سمية الفلوريد عن طريق استخدام الثيموكوينون في ذكور الفئران البيضاء البالغة رشا الحسيني و هدى محمد صلاح الدين'

يوجد الفلورين في الطبيعة في أشكال متعددة، كما أن مركباته تستخدم على نطاق واسع. ويعتقد أن الآثار السامة للفلورين على الأنسجة

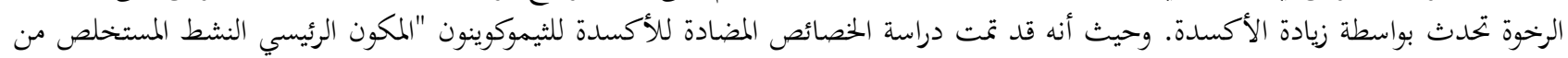

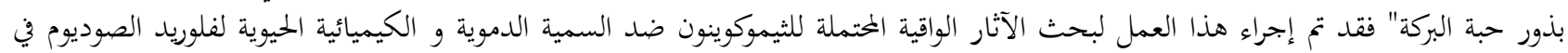
ذكور الفئران البيضاء البالغة.

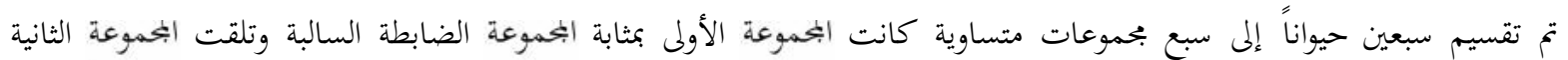

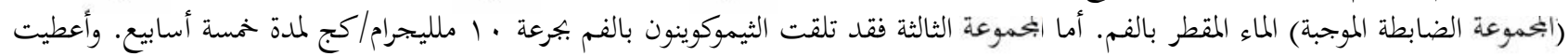

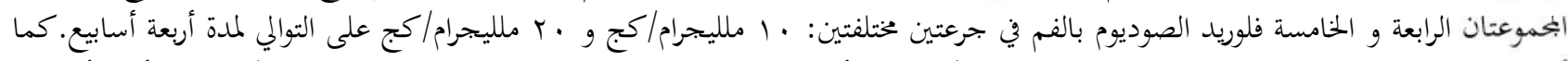

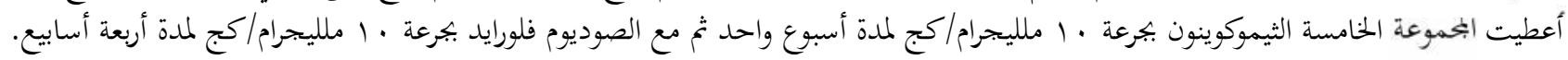

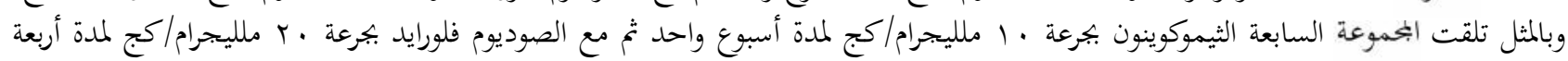

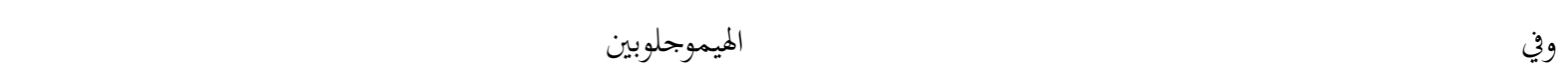

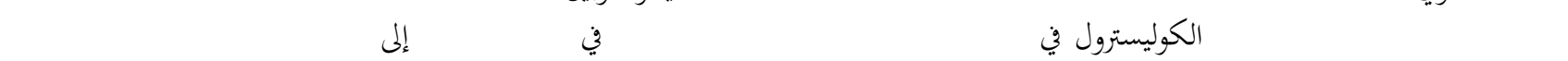

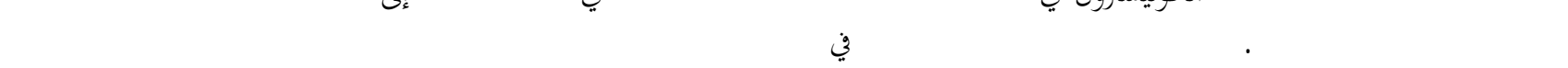

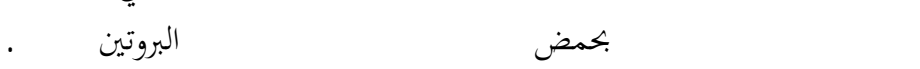
أنتائج:

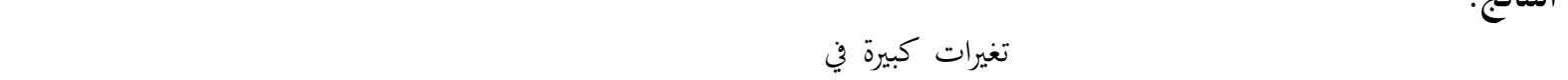

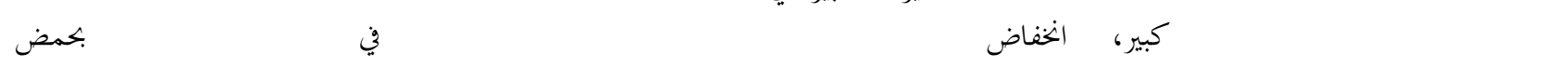

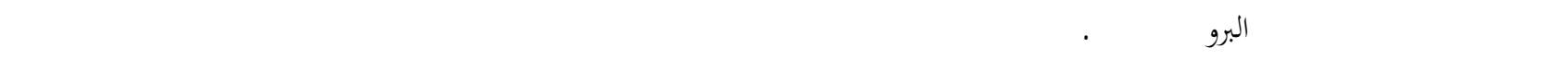

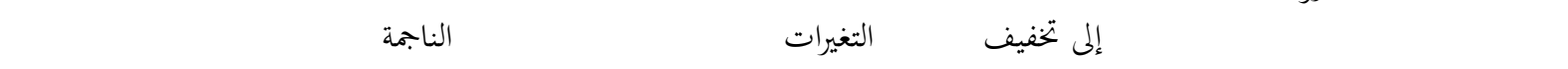

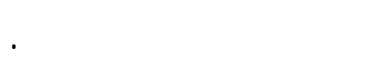

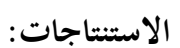
التنائج التئنات الهصلو عليها تشير إلى دور الأكسة في سمية فلويد الصوديه وتشير إلى التأثير القائي للثيموكونون ضد سمية مركبت 